Vol. 1 No. 1 Juli - Desember 2013, pp. 1-8

\title{
PERANGKAT SOAL BERBASIS KONFLIK KOGNITIF
}

\author{
Iskandar Zulkarnain
}

\begin{abstract}
Abstrak
Konflik kognitif adalah kesadaran individu tentang adanya ketidaksesuaian antara struktur kognitif mereka dengan informasi yang mereka hadapi. Konflik pada siswa dapat muncul secara alami dan dapat juga direncanakan secara bermakna oleh guru, yang ditujukan untuk mengatasi kesalahan konsep siswa. Memunculkan konflik kognitif dapat dilakukan diantaranya dengan menyajikan data ganjil. Dalam pembelajaran matematika, data ganjil dapat berupa soal-soal dengan struktur tidak lengkap (ill-structure). Makalah ini mengetengahkan beberapa materi dalam topik aljabar kelas sepuluh yang berpotensi memunculkan konflik kognitif disertai beberapa contoh soalnya. Contoh-contoh soal ini dapat dijadikan sebagai instrumen guna mengukur kemampuan pemahaman relasional.
\end{abstract}

Kata Kunci: konflik kognitif, instrumen tes, materi aljabar, pemahaman relasional

\section{Pendahuluan}

Salah satu elemen penting dalam suatu penelitian adalah instrumen. Instrumen penelitian adalah segala peralatan yang digunakan untuk memperoleh, mengolah, dan menginterpretasikan informasi atau data dari para responden. Sebagai alat pengumpul data, sebuah instrumen harus memenuhi kriteria yang telah ditetapkan, yaitu baik dan benar. Instrumen yang baik dan benar akan menghasilkan data yang baik, benar dan dapat dipercaya sehingga kesimpulan yang dihasilkan juga benar dan dapat dipercaya sebagaimana yang diharapkan dalam suatu penelitian.

Makalah ini memaparkan tentang desain instrumen tes berbasis konflik kognitif pada topik aljabar di sekolah menengah atas. Oleh karena itu, kriteria yang digunakan disesuaikan dengan kebutuhan dan kegunaannya. 


\section{Strategi Penugasan Konflik Kognitif dalam Pembelajaran Matematika}

Beberapa penelitian dalam pendidikan matematika menggunakan konflik kognitif sebagai strategi untuk mengembangkan kesadaran siswa tentang kesalahpahaman mereka dan mendukung pemahaman konsep aljabar (Tall, 1977; Fujii, 2003; Zazkis \& Chernoff, 2006; Fraser, 2007; Sela, 2008).

Konflik kognitif adalah sebuah strategi yang menunjukkan ketidaksesuaian yang terjadi pada dua hal, yaitu antara struktur kognitif seseorang dan lingkungannya (berupa informasi dari luar), atau diantara komponen-komponen yang berbeda (contohnya, ide, keyakinan, dan lainnya) dari struktur kognitif seseorang. Menurut Fraser (2007) konflik kognitif adalah kesadaran individu tentang informasi yang bertentangan yang berdampak pada sebuah konsep pada struktur kognitif itu sendiri. Dampak ini bisa konstruktif atau destruktif. Manakala siswa tertarik atau menaruh minat untuk menyelesaikan kontradiksi tersebut maka hasilnya adalah konstruktif, sedangkan siswa yang frustasi atau tertekan dengan kontradiksi yang dihadapinya maka hasilnya bisa destruktif.

Konflik kognitif biasanya dipicu oleh ketidaksesuaian antara konsep awal individu dengan konsep baru yang dipelajarinya. Hal ini dapat diilustrasikan saat siswa berhadapan dengan soal yang tidak mempunyai sinyal tanda berhenti, seperti $x=k$ dengan $k$ adalah bilangan riil. Artinya siswa kehilangan variabel yang seharusnya ditemukan dalam soal tersebut.

Berdasarkan teori Piaget, ketika seorang anak dapat
mengidentifikasi konflik kognitif (Piaget menggunakan istilah
disekuilibrium), pengidentifikasian ini dapat memotivasinya untuk berusaha
memecahkan permasalahan tersebut. Piaget menyebut proses ini sebagai
pemecahan permasalahan "ekuilibrasi”, yaitu sebuah proses dari pengaturan
diri yang melakukan penyeimbangan antara asimilasi dan akomodasi.

Asimilasi dan akomodasi penting untuk proses ekuilibrasi. Piaget berpendapat bahwa ada gerakan yang kuat antara keadaan ekuilibrium kognitif dan disekuilibrium saat asimilasi dan akomodasi bekerja sama 
JPM IAIN Antasari

Vol. 1 No. 1 Juli - Desember 2013, pp. 1-8

dalam menghasilkan perubahan kognitif (Santrock, 2008). Ada sebuah kontrol biologis yang digunakan untuk mengejar sebuah keadaan yang optimal tentang keseimbangan antara struktur kognitif seorang individu dengan lingkungan yang ditempatinya. Ketika seseorang berinteraksi dengan lingkungannya, orang itu akan mencapai proses ekuilibrasi jika struktur kognitif yang sudah ada bekerja dengan baik untuk menjelaskan pengetahuan yang baru didapatkan. Ketika struktur kognitif yang sudah ada gagal untuk bereaksi terhadap informasi yang baru, terjadilah konflik kognitif yang menyebabkan indvidu melakukan pengejaran terhadap reekulibrasi melalui struktur kognitif yang ada. Individu itu akan beranjak naik ke tingkat perkembangan ekuilibrasi yang lebih tinggi setelah proses akomodasi terlaksana.

Berlyne (Sela \& Zaslavsky, 2007) menyebutkan bahwa strategi konflik kognitif ini (ia menyebutnya dengan istilah conceptual conflict) sangat berpotensi untuk memotivasi siswa dalam memecahkan permasalahan dengan mencari informasi baru atau dengan mencoba menata ulang wawasan yang telah mereka dapatkan, sedangkan Fujii (2003) menggunakan konflik kognitif sebagai alat untuk menganalisis dan menilai kualitas dan kedalaman pemahaman siswa dalam pelajaran aljabar. Strategi yang digunakannya mengikuti cara yang secara nyata menentang ide-ide siswa yang sudah ada dalam rangka untuk memberanikan siswa mengidentifikasi masalah pemahaman mereka sendiri dan untuk memotivasi mereka dalam membangun sebuah pemahaman yang tepat dalam menyelesaikan suatu masalah.

Sementara itu setelah melalui kajian yang ekstensif, beberapa studi mengembangkan metode untuk mengatur konflik kognitif yang telah membawa ke perkembangan tentang kognitif. Sintaks metode itu adalah (Fraser, 2007) :

1. Sebuah pengantar tentang hubungan dan konteks konsep

2. Presentasi dari masalah yang akan memunculkan konflik kognitif 
3. Setelah mengalami konflik kognitif, penting untuk memberikan sebuah lingkungan yang akan memfasilitasi resolusi konflik yang tepat.

Pengenalan konsep diberikan dalam bentuk meminta subjek untuk memecahkan sebuah konflik dan membahas bagaimana mereka memecahkannya, sedangkan konflik kognitif dapat dimunculkan dengan memberikan contoh yang berpotensi memunculkan konflik, dimana umumnya metode penyelesaian yang diberikann subjek sudah diketahui gagal dalam memecahkan konflik. Adapun lingkungan setelah konflik bervariasi, tetapi perlu diberikan sebuah pemikiran alternatif yang dapat mereka pahami. Hal ini biasanya dilakukan dengan memberikan penjelasan tentang mengapa sebuah metode bisa gagal atau mempertahankan mengapa suatu metode lebih unggul diatas yang lainnya.

Berkaitan dengan resolusi konflik, Zazkis dan Chernoff (2006) memberikan pendekatan dalam membantu siswa mengatasi konflik melalui contoh yang disebutnya sebagai pivotal-bridging example. Contoh penting (pivota) menurut mereka, menciptakan titik balik dalam persepsi kognitif siswa atau dalam pendekatan pemecahan masalah siswa. Contoh-contoh tersebut dapat memperkenalkan sebuah konflik atau mungkin mengatasinya. Ketika sebuah contoh penting membantu dalam penyelesaian konflik, mereka menyebutnya sebagai contoh penting yang menjembatani (pivotal-bridging example), atau sederhananya contoh yang menjembatani, yaitu, sebuah contoh yang berfungsi sebagai jembatan dari konsep siswa yang naif kepada konsep matematika yang tepat. Melalui contoh ini siswa digiring atau diarahkan untuk menyelesaikan masalah yang dihadapinya.

\section{Rancangan Instrumen Tes Berbasis Konflik Kognitif}

Lee dan Kwon (2001) meninjau beberapa penelitian konflik kognitif dan mengumpulkan sejumlah tanda yang bisa dilihat yang mengindikasikan seorang siswa mengalami konflik kognitif. Tanda dari 
JPM IAIN Antasari

Vol. 1 No. 1 Juli - Desember 2013, pp. 1-8

konflik kognitif adalah tidak tentu dan tidak jelas ketika seorang siswa mengenali sebuah kontradiksi terhadap harapan mereka, keraguan dan penilaian kembali tentang situasi untuk mencoba menyelesaikan konflik, rasa penasaran yang ditimbulkan dan minat yang bertambah pada sebuah situasi, dan tekanan, frustasi, dan kekhawatiran pada sebuah pertanyaan yang lebih sulit untuk dipecahkan dibandingkan dengan yang diharapkan. Reaksi-reaksi tersebut dapat digunakan untuk menilai manakala seorang siswa mengalami konflik kognitif.

Untuk mengetahui apakah strategi konflik kognitif dapat meningkatkan kemampuan siswa, diperlukan sebuah pengujian melalui seperangkat tes. Penelitian yang dilakukan oleh Sfard dan Linchevski (1994); Fujii (2003); dan Fraser (2007) memberikan jenis pertanyaan yang berpotensi memunculkan konflik kognitif. Materi matematika SMA kelas $X$, jenis pertanyaan tersebut meliputi: pertidaksamaan kuadrat yang tidak mempunyai solusi atau solusi yang tak hingga; persamaan dan pertidaksamaan (atau sistem persamaan dan pertidaksamaan) yang memiliki solusi tak hingga serta persamaan parametrik. Berikut adalah contoh berurutan dari tiap tipe:

1. Selesaikan $x^{2}=x+1>0$ untuk

2. Selesaikan $2(3-x)=-2 x+62$ untuk $x$

3. Selesaikan untuk $b$ sehingga sistem ini tidak memiliki penyelesaian:

$$
\left\{\begin{array}{c}
y=2 x+b \\
y \quad=-2(x-1)^{2}+2
\end{array}\right.
$$

Lebih lanjut Linchevski dan Sfard (1994) memberikan siswa sepasang persamaan dan pertaksamaan yang pada beberapa kasus ekivalen dan tidak dapat ditransformasi secara prosedur satu sama lain, dan di lain kasus tidak ekivalen tetapi sangat bisa dicoba oleh para siswa untuk mentransformasikan satu dengan yang lainnya. Contohnya:

4. Apakah dua persamaan ini memiliki penyelesaian yang sama?

$$
(x-3)^{2}=0 \text { dan } 5 x-4=2 x+5
$$


5. Apakah dua pertaksamaan ini memiliki penyelesaian yang sama? $4 x^{2}>9$ dan $2 x>3$

Selain tipe-tipe soal tersebut, Sela (2008) mengajukan soal yang juga berpotensi memunculkan konflik kognitif pada siswa. Jenis soal ini disebutnya sebagai Challenging Procedural knowledge. Metodenya, siswa dihadapkan pada sebuah kontradiksi karena perbedaan antara hasil yang mereka dapatkan dengan mengaplikasikan prosedur pengetahuan dan hasil orang lain yang mereka dapatkan dengan menggunakan "metode" lain untuk memecahkan soal yang sama. Untuk kontradiksi ini, peneliti menggunakan konsep ekivalensi dalam memecahkan persamaan dan pertidaksamaan. Bedasarkan hasil temuan penelitian, kebanyakan siswa menyelesaikan persamaan dengan menggunakan pengetahuan prosedural mereka tanpa mempertimbangkan kesetaraan antara persamaan asal dan persamaan yang diturunkan siswa dengan melakukan operasi pada kedua sisi persamaan. Contoh untuk tipe soal ini adalah :

6. Selesaikan pertidaksamaan ini : $\sqrt{x-2} \geq 4-x$

Banyak siswa melakukan "prosedur" untuk menyelesaikan persamaan dan pertidaksamaan dengan melakukan operasi pada kedua belah sisi tanpa memperhatikan konsekuensinya. Dalam soal ini, siswa biasanya mengkuadratkan kedua sisi pertidaksamaan tanpa berpikir tentang apakah hasil pertidaksamaan memiliki solusi yang sama seperti semula. Bila prosedur ini yang dilakukan maka solusi dari soal tersebut adalah selang $3 \leq x \leq 6$. Sementara siswa lainnya yang menggunakan metode grafis akan memperoleh hasil pada selang $x \geq 3$. Hasil yang berbeda ini tentu berpotensi memunculkan konflik kognitif pada siswa.

Selain contoh pada nomor enam untuk jenis yang sama, Wahyudin (2011) menambahkan soal logika. Ilustrasinya, selidikilah apakah pernyataan ini bernilai benar atau salah: "jika $x^{2}<4$ maka $x<4$ ". Untuk menjawab soal ini, biasanya siswa akan menjabarkan $x^{2}<4$ menjadi $(x-2)(x+4)<4$ dan menyelesaikannya sehingga sampai pada 
JPM IAIN Antasari

Vol. 1 No. 1 Juli - Desember 2013, pp. 1-8

kesimpulan $-2<x<2$. Selanjutnya, siswa akan menuliskan pernyataan tersebut dengan kalimat yang baru yaitu, jika $x^{2}<4$ maka $-2<x<2$. Dengan demikian, siswa akan meyimpulkan pernyataan asal bernilai salah, karena pada soal konsekuen hanya dibatasi pada selang $x<2$ yang seharusnya berdasarkan perhitungan adalah $-2<x<2$. Sementara itu bila pernyataan tersebut diselidiki dengan pendekatan kontraposisi, yakni “jika $x \geq 2$ maka $x^{2} \geq 4$ “, maka menjadi sebuah pernyataan yang bernilai benar, yang berarti pernyatan asal juga benar, karena nilai kebenaran implikasi ekivalen dengan nilai kebenaran untuk kontrapoisinya. Kasus ini menunjukkan bahwa dengan pendekatan lain, suatu persoalan dapat diselesaikan dengan tepat, sementara pendekatan prosedural akan memberikan hasil yang keliru. Sekali lagi dapat dikatakan bahwa perbedaan hasil ini tentu berpotensi memunculkan konflik.

Beberapa tipe pertanyaan yang diilustrasikan tersebut efektif dalam menguji pemahaman relasional siswa, karena masing-masing berisi suatu hal yang disebut oleh Fraser (2007) sebagai “perangkap procedural”. Hal ini adalah sebuah titik pada penyelesaian prosedural dimana prosedur yang diajarkan pada siswa mengarah pada hasil yang ganjil. Hasil yang ganjil ini hanya dapat dipecahkan jika siswa menguasai pemahaman yang dalam dari sebuah proses. Tidak ada prosedur hapalan untuk menyelesaikan persoalan tersebut. Para siswa dipaksa untuk masuk ke ranah luar prosedur standar mereka dan harus menghubungkan hasil yang ganjil pada struktur yang mendasari sebuah konflik.

Para siswa yang memiliki sebuah pemahaman prosedural menganggap perangkap ini tidak mungkin diselesaikan dengan tepat. Contohnya ketika variabel yang muncul pada sebuah persamaan seperti soal nomor 2, yakni soal dengan solusi yang tidak terhingga. Melalui prosedur yang lazim, siswa akan sampai pada hasil $x=x$ atau $0=0$. Tidak ada cara untuk menghasilkan bentuk yang diharapkan seperti misalnya $x=a$ dengan $a$ bilangan real yang merupakan sinyal berhenti. Pada keadaan yang demikian, siswa yang tidak memiliki pemahaman yang dalam 
akan merasa frustasi karena tidak memperoleh solusi dari persoalan tersebut.

Pada contoh-contoh yang telah dipaparkan sebelumnya, terlihat peran dari data ganjil berpotensi memunculkan konflik kognitif, tetapi menurut Limón (2001) pemberian data yang ganjil adalah salah satu strategi untuk mendapat konflik kognitif, tetapi bukan satu-satunya. Menurutnya analogi dan metafora atau pembahasan dengan teman atau dalam kelompok mungkin bisa membuat para siswa ke konflik kognitif yang bermakna, misalnya :

7. Diberikan persamaan-persamaan berikut (Fraser, 2007):
A. $(x+2)(x-2)=(x-2)$ dan
B. $x^{2}-4=x-2$

Andi dan Fahmi, dua siswa di kelas lain menjawab soal tersebut dan jawaban mereka sebagai berikut :

Jawaban Andi : $\quad$ Jawaban Fahmi :
A. $x=-1$
A. $x=2 ; x=-1$
B. $x=2 ; x=-1$
B. $x=2 ; x=-1$

Anda berada pada pihak yang mana ? Jawaban siapa yang benar ? Jelaskan jawaban anda!

Demikian beberapa soal yang berpotensi memunculkan konflik kognitif pada siswa. Jenis pertama mungkin dapat dikategorikan sebagai soal yang bila diselesaikan dengan prosedur lazimnya akan menghasilkan jawaban yang aneh, karena tidak ada tanda berhenti. Jenis kedua adalah soal yang menantang prosedural, artinya jawaban yang dihasilkan siswa melalui prosedur umum akan memberikan hasil yang kurang tepat, dimana pada kasus tersebut, diperlukan metode atau pendekatan lain untuk memberikan solusi yang benar. Sedangkan jenis ketiga adalah soal dengan metafora, yaitu soal yang disertai solusi sebagai pembanding.

Berdasarkan konsep-konsep di atas, dapat dirancang seperangkat instrumen berbasis konflik kognitif untuk mengukur kemampuan 
JPM IAIN Antasari

Vol. 1 No. 1 Juli - Desember 2013, pp. 1-8

pemahaman matematis siswa sekolah menengah atas dalam memecahkan masalah matematis, yaitu :

1. Carilah penyelesaian pertidaksamaan berikut : $x^{2}+x>-1$

2. Carilah penyelesaian dari $3(7-5 x)=-15 x+21$

3. Untuk nilai $k$ berapakah sehingga sistem persamaan berikut mempunyai penyelesaian : $\left\{\begin{array}{c}2 x+y=k \\ y=3+k\end{array}\right.$

4. Apakah dua pertidaksamaan $4 x^{2}>9$ dan $2 x>3$ mempunyai penyelesaian yang sama? Jelaskan jawaban saudara!

5. Diberikan persamaan:

a. $(x-3)(x+3)=(x+3)$ dan b. $x^{2}-9=x+3$

Revy dan Aniz dua siswa di kelas lain menjawab soal tersebut dan jawaban mereka adalah :

Jawaban Revy Jawaban Aniz
(a) $x=4$
(a) $x=-3 ; x=4$
(b) $x=-3 ; x=4$
(b) $x=-3 ; x=4$

Anda berada di pihak siapa ? Menurut anda jawaban siapa yang benar? Dapatkah anda memberikan penjelasan ?

Beberapa argumentasi sederhana mungkin dapat menjelaskan tentang keunikan soal tersebut. Ekspresi aljabar pada soal pertama tidak dapat difaktorkan, sehingga siswa biasanya akan menguji diskriminan dan mendapatkan nilai $D=-3$. Karena diskriminan bernilai negatif, siswa cenderung menyimpulkan bahwa solusinya tidak ada atau solusinya bilangan imajiner. Sementara siswa yang memiliki pemahaman relasional akan mengunakan pendekatan kuadrat sempurna guna mengubah ekspresi aljabar menjadi $\left(x+\frac{1}{2}\right)^{2}+\frac{3}{4}>0$, sehingga berapapun nilai $x$ akan memenuhi.

Pada soal kedua, secara prosedural siswa akan sampai pada $21-15 x=-15 x+21$ atau $0=0$. Kebanyakan siswa akan bingung, karena variabel $x$ hilang atau tidak mendapatkan sinyal tanda berhenti, misalnya 
$x=a$. Demikian juga pada soal ketiga, konstanta $k$ hilang sedangkan nilai $x$ dapat ditemukan. Tentu saja ini persoalan yang rumit bagi siswa biasa, akan tetapi siswa yang memiliki pemahaman mendalam tidak akan terjebak dengan perangkap prosedural ini. Siswa akan menyebutkan bahwa $x$ pada soal kedua dapat menjadi bilangan apapun demikian juga nilai konstanta $k$ di soal ketiga.

Pada soal keempat, siswa yang menerapkan prosedur dengan menarik akar akan menjawab bahwa dua pertidaksamaan mempunyai solusi yang sama. Sementara siswa yang memiliki pemahaman relasional akan memandang bahwa kedua pertidaksamaan memiliki struktur yang berbeda. Secara geometris, pertidaksamaan pertama berupa parabola, sedangkan pertidaksamaan kedua berupa garis lurus.

Untuk soal terakhir, siswa dihadapkan pada solusi pembanding. Solusi untuk soal tersebut sudah diberikan, dan mereka diminta memilih berada pada pihak yang mana. Untuk berpihak pada salah satu jawaban, tentu dituntut kemampuan memberikan argumen yang didukung oleh fakta berupa solusi soal tersebut. Salah satu dari jawaban yang diberikan pasti benar, sehingga tidak ada alternatif atau jawaban yang lain. Siswa didorong untuk memilih jawaban dengan argumentasi yang sahih.

\section{Kesimpulan}

Instrumen merupakan alat yang penting untuk menggali data dalam suatu penelitian. Penyusunannya disesuaikan dengan kebutuhan dan kegunaannya. Instrumen ini disusun berbasis konflik kognitif, berupa seperangkat soal yang memuat jebakan prosedural. Siswa yang hanya memiliki pemahaman prosedural tanpa penguasaan konsep kuat akan gagal dalam menyelesaikan soal tersebut. Dengan demikian guru sekolah menengah perlu mendesain pembelajaran di kelas yang tidak hanya mengajarkan kemampuan prosedural saja, tetapi juga diharapkan dapat mengembangkan pemahaman relasional siswa. 
JPM IAIN Antasari

Vol. 1 No. 1 Juli - Desember 2013, pp. 1-8

\section{Daftar Pustaka}

Fujii, T. (2003). Probing Student's Understanding of Variables Through Cognitive Conflict Problem. Is the Concept of a Variable so Difficult for Student to Understand? [Online]. Tersedia:

http//onlinedb.terc.edu/PME2003/PDF/Plen5fujii.pdf [26 Pebruari 2010]

Fraser, D.(2007). Using Cognitive Conflict to Promote a Structural Understanding of Grade 11 Algebra. [Online]. Tersedia: http://ir.lib.sfu.ca/handle/1892/9437 [1 Desember 2010]

Lee, G \& Kwon, J. (2001). What Do We Know about Students' Cognitive Conflict in Science Classroom: A Theorical Model of Cognitive Conflict Process. [Online]. Tersedia: http://www.eric.ed.gov/ERIC/WebPortal [18 Mei 2010]

Limón, M. (2001). On the Cognitive Conflict as an Instructional Strategy Conceptual Change: a Critica Appraisal.

Pegg,J. \& Tall, D. (2005). The Fundamental Cycle of Concept Construction Underlying Various Theoritical Frameworks. [Online]. Tersedia: www.warwick.ac.uk/Staff/David.Tall/pdfs/dot2005h-zdm-peggtall.pdf [11 Pebruari 2011]

Piaget, J. (1952). The Origins of Intelligence in Children. New York: International Universities Press, Inc.

Rolka, K., Rosken B. \&Liljedahl P. (2007). The Role of Cognitive Conflict in Belief Changes. [Online]. Tersedia:

http://www.emis.de/proceedings/PME31/4/120.pdf [11 November 2009]

Santrock, JW. (2008). Psikologi Pendidikan, edisi kedua. Jakarta: Kencana.

Sela, H. \& Zaslavsky, O. (2007). Resolving Conflict Cognitive with Peers - Is There a Difference between Two and Four? [Online]. Tersedia: http//www.emis.de/proceedings/PME31/4/168.pdf [26 Pebruari 2010]

Sela, H. (2008). Coping with Mathematical Contradictions with Peers. [Online]. Tersedia: http//tsg.icme11.org/document/get/632 [28 Pebruari 2010]

Tall, D. (1977).Cognitive Conflict and the Learning of Mathematics. [Online]. Tersedia: 
http://www.warwick.ac.uk/staff/David.Tall/pdfs/dot1977a-cogconfl-pme.pdf [21 Januari 2010]

Zazkis, R. \& Chernoff, E. (2006).Cognitive Conflict and its Resolution via Pivotal/Bridging Example. [Online]. Tersedia:

http//wWw.emis.de/proceedings/PME30/5/465.pdf [20 Januari 2010] 